DOI https://doi.org/10.30525/978-9934-588-79-2-2.18

\title{
СТАНДАРТНІ ПОКАЗНИКИ ЯКОСТІ ТА БЕЗПЕКИ У ТЕХНОЛОГІЇ КОМПЛЕКСНОЇ ПЕРЕРОБКИ ТОПІНАМБУРА
}

\author{
Лазаренко Н. А. \\ кандидат технічних наук, \\ старший викладач кафедри технології \\ ресторанного і оздоровчого харчування \\ Одеської національної академії харчових технологій \\ Біленька I. P. \\ кандидат технічних наук, \\ доцент кафедри технології ресторанного і оздоровчого харчування \\ Одеської національної академії харчових технологій \\ м. Одеса, Украӥна
}

У даний час головним критерієм при оцінці благополуччя населення країни $є$ показник якості життя. Одним із найважливіших чинників, який впливає на якість життя та стан здоров'я визнано харчування людини, тому в останні роки велику увагу привертають показникам якості та безпеки продукції.

Різноманіття продуктів, які виготовляє харчова промисловість, у т.ч. заклади ресторанного господарства, надає можливості споживачам обрати найбільш якісний товар, який являє для них високу цінність, виходячи з їх уяви про якість. У даному випадку, якість характеризує сукупність властивостей продукту, які зумовлюють його придатність до споживання та задовольняють потреби споживачів у продуктах харчування.

Основними чинниками, що визначають необхідність забезпечення і підвищення якості продуктів $\epsilon$ зростання потреб у якісному харчуванні, збільшення темпів науково-технічного прогресу щодо розвитку науки та технологій виробництва кулінарних страв, підвищення ефективності виробництва, посилення конкуренції на внутрішніх і світових ринках [1, с. 39; 2, с. 187-193].

В умовах швидкого розвитку ресторанного консалтингу на світовому ринку актуальною для всіх країн $\epsilon$ проблема забезпечення якості виробництва кулінарних страв. Правильний підхід до управління на всіх технологічних етапах полягає в забезпеченні належної якості продуктами, оскільки лише продукція належної якості може бути 
конкурентоспроможною [3, с. 57]. Так, основні етапи контролю якості продукції у закладах ресторанного господарства представлені на рис. $1[4$, с. 256$]$.

\begin{tabular}{|c|c|c|c|}
\hline 롤 & Eтan & $\begin{array}{l}\text { Контроль } \\
\text { прочесу } \\
\text { постачани } \\
\text { я сировини, } \\
\text { купівеньних } \\
\text { товарів й } \\
\text { иапів- }\end{array}$ & $\begin{array}{l}\text { - перевірка відповідності видів і найменувань сировини товарно- } \\
\text { супровідним документам; } \\
\text { - оцінка порядку приймаиня товариих запасів за якісиими та } \\
\text { кількісними показниками; } \\
\text { - контроль організаціг складського господарства иі правильності } \\
\text { зберігання товарних запасів; } \\
\text { - інспектування збереження товарних запасів (режим температури, } \\
\text { вологості тощо) }\end{array}$ \\
\hline$\frac{2}{2}$ & ET & $\begin{array}{l}\text { Контроль } \\
\text { порядку } \\
\text { виготовлен } \\
\text { ня страв } \\
\text { власного } \\
\text { виробницт } \\
\text { ва }\end{array}$ & $\begin{array}{l}\text { - перевірка дотримашия закладки сировини у відповідності до } \\
\text { встановлених норм та порндку здійснення виробничого процесу; } \\
\text { - оцінка достовірності списанн снровини, виходу напівфабрикатів і } \\
\text { готової продукцї; } \\
\text { - контроль за втратами під час теплової обробки продукції і нормами } \\
\text { взасмозамінності сировини при приготуванні страв; } \\
\text { - дослідження страв власного виробиицтва на відповідиість } \\
\text { встановленим кількісним та якісним параметрам }\end{array}$ \\
\hline 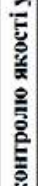 & $\begin{array}{r}\text { ET: } \\
\text { II }\end{array}$ & 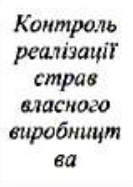 & $\begin{array}{l}\text { - перевірка страв власного виробництва за органолептичними та } \\
\text { фізмко-хімічними показниками; } \\
\text { - оцінка оптимальних умов реалізаніі страв власного виробництва і } \\
\text { купівельних товарів; } \\
\text { - виявлення продукціі, шо не відповідас замовленню покупця або ж } \\
\text { встановленим параметрам; } \\
\text { - контроль за якістю та свосчасністо виконання отриманого } \\
\text { замовлення }\end{array}$ \\
\hline & $\underset{\text { IV }}{\text { Eran }}$ & $\begin{array}{l}\text { Oуінка } \\
\text { надания } \\
\text { постуг } \\
\text { pecmopanн } \\
\text { ого } \\
\text { zocnodapcm }\end{array}$ & $\begin{array}{l}\text { - контроль чіткості та оперативності наданих послуг ресторанного } \\
\text { господарства; } \\
\text { - оцінка компетентності персоналу, що надас відповідні послуги; } \\
\text { - перевірка особисто безпеки і безпеки майна відвідувачів закладу; } \\
\text { - перевірка відповдності послуг ресторанного тосподарства } \\
\text { очікуванням відвідувачів }\end{array}$ \\
\hline
\end{tabular}

\section{Рис. 1. Етапи контролю якості у закладах ресторанного господарства}

Об'єктом дослідження була технологія комплексної переробки бульб топінамбура, розроблена в Одеській національній академії харчових технологій в лабораторіях кафедри технології ресторанного i оздоровчого харчування. Так як якість продукції, в першу чергу, визначають за показниками безпеки, обрані сорти топінамбура досліджували на наявність важких металів та нітратів (табл. 1).

Результати досліджень, що представлені в таблиці 1 підтверджують літературні дані [5, с. 77-78] відносно властивості бульб топінамбура майже не накопичувати важких металів та нітратів. Вміст нітратів для сорту Інтерес в порівнянні з сортом Violet de Rennes на 7 мг/кг менше, а за показником добової норми менше на 35 мг/кг. 
Таблиця 1

Вміст важких металів та нітратів в бульбах топінамбура

\begin{tabular}{|c|c|c|c|}
\hline \multirow{2}{*}{ Показник } & \multirow{2}{*}{$\begin{array}{c}\text { Допустима норма } \\
\text { показника } \\
\text { в свіжих овочах, } \\
\text { мг/кг не більше } \\
\end{array}$} & \multicolumn{2}{|c|}{ Сорт топінамбура } \\
\hline & & Інтерес & Violet de Rennes \\
\hline Свинець & 0,3 & не виявлено & не виявлено \\
\hline Кадмій & 0,02 & не виявлено & не виявлено \\
\hline Ртуть & 0,01 & не виявлено & не виявлено \\
\hline Мідь & 5,0 & 0,02 & 0,02 \\
\hline Цинк & 10,0 & 2,3 & 2,5 \\
\hline Миш'як & 0,2 & не виявлено & не виявлено \\
\hline Нітрати & 80 & 45 & 52 \\
\hline
\end{tabular}

У відповідності до плану комплексної переробки бульб топінамбуру, було передбачено отримання наступних продуктів: цукати, сік 3 ферментованого топінамбура, овочева паста.

Для встановлення органолептичних показників якості розроблених продуктів проводили дегустаційну оцінку експериментальних зразків, результати якої представлені в таблиці 2.

Таблиця 2

Органолептичні показники якості розробленої продукції

\begin{tabular}{|l|l|l|l|}
\hline \multirow{2}{*}{$\begin{array}{c}\text { Найменування } \\
\text { показника }\end{array}$} & \multicolumn{3}{|c|}{ Цурактеристика } \\
\cline { 2 - 4 } & \multicolumn{1}{|c|}{ Цукатин } & \multicolumn{1}{|c|}{ Сік } & \multicolumn{1}{|c|}{ Овочева паста } \\
\hline Зовнішній вид & $\begin{array}{l}\text { Мають рівну поверх- } \\
\text { ню та рівномірно } \\
\text { обсипані фруктозою } \\
\text { і пектином, не мають } \\
\text { ознак псування } \\
\text { (плісняви, бродіння) }\end{array}$ & $\begin{array}{l}\text { Рідина без } \\
\text { м'якоті, може } \\
\text { мати незначний } \\
\text { осад }\end{array}$ & $\begin{array}{l}\text { Напіврідка гомо- } \\
\text { генна структура, } \\
\text { без сторонніх } \\
\text { включень }\end{array}$ \\
\hline Смак і запах & $\begin{array}{l}\text { Виражений присмак } \\
\text { карамелі з включен- }\end{array}$ & $\begin{array}{l}\text { Кислувато- } \\
\text { солодкий, без } \\
\text { стороннього } \\
\text { ням присмаку топі- } \\
\text { намбура }\end{array}$ & $\begin{array}{l}\text { Кислувато- } \\
\text { солодкий, } \\
\text { без стороннього } \\
\text { присмаку та з }\end{array}$ \\
& $\begin{array}{l}\text { легким запахом } \\
\text { м'яти перцевої }\end{array}$ & примним запахом \\
\hline Колір & $\begin{array}{l}\text { Однорідний по всій } \\
\text { масі, жовтого чи } \\
\text { світло коричневого } \\
\text { кольору, напівпрозорі }\end{array}$ & $\begin{array}{l}\text { Однорідний по } \\
\text { всій масі, пома- } \\
\text { ранчевого ко- } \\
\text { льору }\end{array}$ & $\begin{array}{l}\text { Однорідний по } \\
\text { всій масі, жовтого } \\
\text { чи світло коричне- } \\
\text { вого кольору }\end{array}$ \\
\hline Консистенція & $\begin{array}{l}\text { Щільна, крихка, при } \\
\text { натисканні волога не } \\
\text { виділяється }\end{array}$ & $\begin{array}{l}\text { Рідина, без явно } \\
\text { вираженого } \\
\text { осаду }\end{array}$ & $\begin{array}{l}\text { Пюреподібна, } \\
\text { однорідна, без } \\
\text { сторонніх включень }\end{array}$ \\
\hline
\end{tabular}


Органолептичний аналіз дозволяє швидко оцінити якість кулінарної страви та виявити порушення рецептури, або технології виробництва, що надає можливості швидко вжити заходів стосовно усунення виявлених недоліків. При проведенні органолептичного аналізу якість страв оцінювали за наступними показниками: зовнішнім виглядом, запахом і смаком, кольором та консистенцією. За результатами органолептичної оцінки та проведених досліджень можна стверджувати, що розроблена продукція на основі топінамбура має добрі смакові якості.

Таким чином, першочерговими критеріями, за якими повинна оцінюватися продукція закладів ресторанного господарства $є$ стандартні для тих чи інших страв показники якості та безпеки, тому на виробництві необхідно практикувати безперервний контроль виконуваних процесів з виготовлення продукції належної якості, яка буде високо оцінена споживачами.

\section{Література:}

1. Вандяк Н.П. Значення підвищення якості продукції на підприємствах харчової промисловості. Стратегія ресурсозберігаючого використання аграрно-економічного потениіалу на основі активізації інновачійно-інвестииійної діяльності - об'єктивна передумова інтеграиії країни в світове співтовариство: збірник тез міжнар. наук.-техн. конф.(Тернопіль, 18 травня 2007 р.). Тернопіль, 2007. С. 39.

2. Левкулич В.В. Зовнішні та внутрішні фактори впливу на забезпечення та покращення якості продукції. Науковий вісник Ужсгородського університету (Серія Економіка). 2012. Вип. 2(36). С. 187-193.

3. Цюцяк А.Л. Контроль в системі управління якістю на підприємствах ресторанного господарства. Науково-інформаційний вісник «Економіка». 2015. № 12. С. 251-259.

4. Сусол Н., Куць В. Методи контролю якості технологічних операцій виготовлення кулінарної продукції. Вимірювальна техніка та метрологія. 2012. № 73. С. 113-117.

5. Yang L., He Q. S., Corscadden K., Udenigwe C. C. The prospects of Jerusalem artichoke in functional food ingredients and bioenergy production. Biotechnology Reports. 2015. Vol. 5. P. 77-88. doi:10.1016/j.btre.2014.12.004 